\title{
The distribution and habitat of Stenus (Hemistenus) audax J. Sahlberg 1900 (Coleoptera, Staphylinidae) in Finland
}

\author{
Tom Clayhills
}

\begin{abstract}
Clayhills, T. 1991: The distribution and habitat of Stenus (Hemistenus) audax J. Sahlberg 1900 (Coleoptera, Staphylinidae) in Finland. — Entomol. Fennica 2:25-26

The distribution of Stenus audax J. Sahlberg is reviewed and three new finds from northernmost Finland are recorded, all from Utsjoki, Nuorgam.

$S$. audax seems to prefer areas of upwelling cold groundwater surrounded by sparse Carex vegetation or heavy stands of different mosses on hihglying mires in the upper parts of the mountain birch forest zone. The species overwinters as an imago.
\end{abstract}

Tom Clayhills, Tennbyvägen 33-35, B4, SF-21600 Pargas, Finland

On 24 July 1986 I found a specimen of Stenus audax J. Sahlberg on a Carex mire in the mountain birch forest zone some $150 \mathrm{~m}$ a.s.l. at Utsjoki, Nuorgam (777:53) in the biogeographical province of $\mathrm{Li}$.

Stenus audax was described from Finland from one specimen found on the shoreline of the Ivalo river at Kyrö on 24 July 1894 (J. Sahlberg 1900). Later (1951) Yrjö Kangas found one specimen at Nuorgam on the shore of the Pulmanki river (776:53) quite close to the locality where I found the species (I. Rutanen, pers. comm.). From Norway three specimens are known from the Neiden area in Syd-Varanger some $60 \mathrm{~km}$ eastward from Nuorgam (T. Munster 1923). In the USSR the species in known from 3 places, viz. two or three specimens from Archangelsk, probably collected in 1880 (Enwald leg.), three specimens from Kanin in 1909 (Poppius leg.), and one new find, a female from Vorkuta in Komi collected by Shilov in 1972 (V. Puthz 1974). Most of the known specimens were found in Sweden, Lu.Lpm. during the years 196670 in Vietas where a total of about 15 S. audax specimens were collected by B. Ehnström and T.-E. Leiler (S. Lundberg pers. comm.).

In 1987 I returned to the same mire with the aim of trying to locate the microhabitat of S. audax. Thanks to some tips from the late Thure Palm I soon found a place that looked like the appropriate habitat for $S$. audax. To the western side of the mire a small brook running under a layer of stones opened out as a short channel of about $3 \mathrm{~m}$ in length before ending in a small pond among Carex vegetation. Although the day (19.7) was very warm (about $30-31^{\circ} \mathrm{C}$ ), the temperature of the water in the channel was cold (about $4-5^{\circ} \mathrm{C}$ ). I pushed sparse Carex vegetation around the channel under the water and collected all Stenus specimens that floated to the surface. About 1-1 1/2 $\mathrm{m}$ from the beginning of the channel a Stenus specimen floated up to the surface that I immediately recognized as a $S$. audax female . Compared to the other Hemistenus species that occurred in the same habitat, i.e. S. niveus Fauvel, S. umbratilis Casey and S. bifoveolatus Gyllenhal, S. audax seemed to be slow and clumsy. Whilst specimens of the other species 
run quite fast under the water along Carex leaves up to the surface, on which they then run vigorously into the denser Carex vegetation, S. audax bent its abdomen upwards, let go of its support and floated up like a cork to the surface, where it did not make any signs of trying to move away. I did not find any other $S$. audax specimens during my research, either around the channel and the pond, or in the immediate vicinity. Neither did I find any specimens of $S$. audax from any other similar mire nearby. However, during the determination of the material I found one male specimen in the sample taken from the edge of the channel. The male proved to be much more slender than the female, thus closely resembling the S. niveus specimens. It is noteworthy that both $S$. audax specimens were taken from the same small area where the water temperature was low and the Carex vegetation sparse. The temperature in the pond was considerably higher.

On 14 August 1989 I managed to find an additional specimen of $S$. audax from a sloping mire some $200 \mathrm{~m}$ a.s.l. and about $4 \mathrm{~km}$ northward from the former habitat. Sieving litter from under willow bushes, around Carex tuffs and wet moss vegetation around small pools of upwelling groundwater, I managed to obtain, in addition to three $S$. hyperboreus J. Sahlberg specimens, one male of $S$. audax. Two days later I returned to the slope mire where I followed its watercourse from the highest point to the small lake where it ended. The length of the mire is slightly less than one $\mathrm{km}$. The upwelling waterpools are situated in the middle of the mire at the beginning and end of the most sloping part of the mire. The pools were surrounded by a thick moss vegetation consisting of Sphagnum and other mosses. I took a sieve sample from the wet moss vegetation around the pools and along the wettest parts of the watercourse and obtained four more individuals, three males and one female of $S$. audax, which obviously seems to overwinter as an imago. Thus, about 33 specimens of this arctic Staphylinid are known so far. Also in this case the specimens occurred close to the upwelling cold water but here they were living in dense moss vegetation either bare or with sparse stands of Carex. According to Thure Palm and Stig Lundberg (pers.

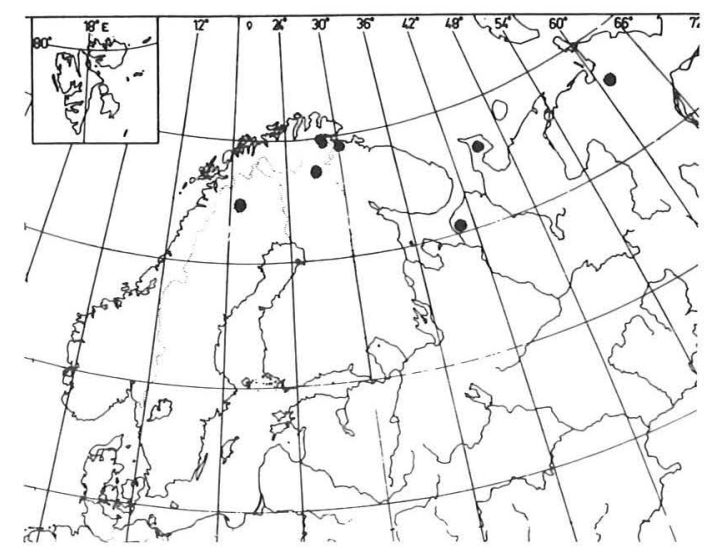

Fig. 1. The distribution of Stenus audax J. Sahlberg.

comm.), S. audax occurs only in one place in Vietas in northern Sweden, where it lives on one mire in the Sphagnum vegetation kept wet by upwelling cold groundwater at the edge of small brooks.

There is fossil evidence examined by V. Puthz from Northmoor, England of a male aedeagus of S. audax from about 11000 years ago (Puthz pers. comm.) which coincides well with the Alleröd interstadial period when the climate in England was cold some 3-4000 years after the Weichsel III glaciation had withdrawn from the British isles. Apparently this cold-loving species has been following the melting ice limit northwards and is now restricted to northernmost Europe above latitude $65^{\circ} \mathrm{N}$ (Fig. 1).

Acknowledgements. I wish to thank Dr. Volker Puthz for permitting me to use his files on Stenus audax.

\section{References}

Munster, T. 1923: Nye fund og findesteder. B. Coleoptera. — Norsk Entomol. Tidskr. 1:257-274.

Puthz, V. 1974: Weitere nordostpaläarktische Stenus-Arten (Coleoptera, Staphylinidae). - Notulae Entomol. 54:107-113.

Sahlberg, J. 1900: Coleoptera nova vel minus cognita faunae Fennica. - Acta Soc. Fauna Flora Fennica 19:123.

Received 19.I.1990 